\title{
The relationship between the quality of work life and employee satisfaction in five star hotels in Cairo
}

\author{
Hanady Mohamed Abu Elmatey
}

Faculty of Tourism and Hotels, Suez Canal University

\begin{abstract}
The aim of this research is to study the relationship between Quality of Work Life (QWL) and employees' satisfaction in hotels. Questionnaires were distributed among employees at five- star hotels in Cairo. The results showed that the quality of work life attributes have a significant effect on employees' satisfaction in general, and especially these attributers (adequate income and fair compensation, and safe and healthy working conditions) that have the largest effect on employees' satisfaction. Based on the results, the study suggested some recommendations for hotels to improve the quality of work life in order to increase employees' satisfaction.
\end{abstract}

Keywords: Quality of Work Life, Employees, satisfaction, hotels.

\section{Introduction}

Human resources play an important role in success of an organization. Many features affect the management of human resources. One of these features is the Quality of Work Life $\left(^{1}\right)$. It is a set of principles, which holds that employees are the most important resource in the organization as they are trustworthy, responsible and capable of making valuable contribution and they should be treated with dignity and respect $\left(^{2}\right)$.

When organizations have an effective QWL, it is a good indicator to boosts its image in attracting and retaining employees. This is important as it indicates that firms are able to offer appropriate working environment to employees. Hence, by having QWL, the firms can enjoy increased organizational productivity and higher opportunity for growth with better participation from employees $\left(^{3}\right)$.

\section{Origin and Meaning of Quality of Work Life}

The quality of work life concept was first introduced at an International Conference on the "Democratization of Work" held at Colombia University's Arden House, New York in 1972 that sought to share knowledge and practice on how to create the conditions for a humane working life $\left(^{4}\right)$. QWL is a process which enables employees to participate actively and efficiently in shaping the organizations environment, methods, procedures and outcomes. It is aimed to meet the goals of enhanced organizational productivity and improved employees satisfaction $\left({ }^{5}\right)$.

The concept of QWL had originally included only the issues of wages, working hours, and working conditions. Nowadays, the concept has been expanded to include other factors such as the extent of employee involvement in the job, accomplishment on the job, motivation of employee, job competence and enhanced productivity and decreases cost $\left({ }^{6}\right)$. QWL is a philosophy of management that believes collaborative relationship among employees and managers, and also believes that every employee has the ability and right to offer opinions and useful inputs into decisions at various levels in the organizations $\left({ }^{7}\right)$.

QWL is also one of the elements contributing to an organization's progress providing motivation, satisfaction and commitment to one's job. This is achieved through creating more democratic job atmosphere and the involvement of employees in decision making in order to improve the organization's performance and productivity $\left({ }^{8}\right)$. It includes opportunities for active involvement in group working arrangements and problem solving that are of mutual benefit to employees and organizations $\left({ }^{9}\right)$.

The objectives of QWL from an organizational perspective are: - to provide appropriate work resources and conditions, improve organizational effectiveness and performance, decrease turnover rate, reduce absenteeism, increase profitability and increase the productivity. Whereas, The objectives of QWL from an employee's perspective are:- to improve the standard of living of the employees, improve physical and psychological health of employees, increase satisfaction, and reduce stress on employees $\left({ }^{10}\right),\left({ }^{11}\right)$.

\section{The Dimensions of Quality of Work Life}

There are eight major dimensions which make up the quality of work life framework, these dimensions are as follows $\left({ }^{12}\right)$ :- 


\section{1- Adequate and fair compensation}

It is one of the most important dimensions of the quality of work life. The important here is that income offered must be adequate implying it must be proportionate to work, and there should be consistency among salaries of employees. People want to see fairness and adequacy in their pay rewards. Salary that is linked to responsibility, skill, performance and individual accomplishment are viewed with great importance.

\section{2- Safe and healthy working conditions}

Organizations must provide working conditions that are physically and psychologically safe for their employees. Unsafe and hazardous working conditions cause problems for both organizations and employees. Many companies improve quality of work life of employees by modifying their work environment. Therefore, adequate investment must be made to ensure safe and healthy working conditions.

\section{3- Opportunities to use and develop human capacities.}

Development of employees involves training, recognition and promotion. Tasks should be made challenging to expand skills, abilities, and knowledge. They should also create a positive effect on self-esteem, autonomy, involvement and incentive. Employees' perception of the quality of their work life depends upon the extent to which jobs allow them not only to use but also to develop their competencies and skills.

\section{4- Opportunities for continued growth and creativity}

Job advancement is one of the major concerns of employees. It is related to the idea of professional learning as a means for career development. QWL encompasses the career development practices used within the organization such as developing road maps for employees in terms of their career growth.

\section{5-Social integration in the work organization}

Relationship between employees and managers is an indicator of healthy work organization. Therefore, formal and informal interactions between employees and managers should be provided. All kind of classes, religions and races must be treated equally in order to create egalitarian in the work environment.

\section{6- Constitutionalism in the work organization}

It is related to organizational norms that affect the freedom of an employee. Efforts should be made to see right norms are formed in the organization. These norms include the privacy of employees, equitable treatment in work, freedom of speech, equity and freedom to dissent on some aspects.

\section{7- The relationship between works and non-work life}

It is an important component of QWL for both the employees and the organizations. In an increasing competitive environment, it is difficult to separate home and work life. Employees today are more likely to express a strong desire to have a harmonious balance among career, family life and leisure activities $\left({ }^{13}\right)$. The continuous hard work causes psychological and physical stresses. Therefore, there has to be a balance between personal and professional life. Organization must create proper work environment to enrich the life of employees. The concept of a balanced work and non-work life encompasses work, career demands, travel requirements and family times.

\section{8- Social relevance of work life}

Employees who feel that their organization is acting in a socially responsible manner, in terms of its products and services, will tend to value their work and careers more highly, which in turn enhance the self-esteem and well-being. Employees must be given the perspective of how their work helps the society. This is essential to build relevance of the employees' existence to the society they live in. Socially responsible behavior includes a wide array of actions such as behaving ethically, supporting the work of nonprofit organizations, treating employees fairly, and minimizing damage to the environment (13).

\section{The advantages of the quality of work life}

The benefits of QWL go to both employees and organizations. Employees trust that with the presence of effective QWL initiatives they feel safe, well satisfied and able to develop human capacities. They believe that QWL enhances their dignity by ensuring job satisfaction, providing safe and healthy working conditions, ensuring growth and security, and thus helping to increase productivity that supports to achieve 
organizational effectiveness. QWL also increases the level of commitment by employees towards their work and the organization $\left({ }^{14}\right)$.

Moreover, a good QWL leads to enhanced organizational efficiency as well as individual efficiency. Organizational efficiency is enhanced through better working condition, improvement in organizational environment, reduction in cost and increasing productivity. Individual Efficiency and productivity is enhanced and leads to development of competencies at work through human resources practices leading to enhanced motivation, job commitment and satisfaction $\left({ }^{15}\right)$. Quality of work life gives employees the opportunity to make decisions about their jobs and the design of their workplaces $\left({ }^{16}\right)$.

\section{Barriers related to quality of work life}

The philosophy of quality of work life is based on the belief in employees' participation. This implies that organizations should allow their employees participate in decisions about conditions or processes which affect their work. A lot of managers may perceive this phenomenon as a challenge to their rights and decisions. They may not be willing to delegate decision-making to employees. Managers believe that employees are inherently lazy, lack responsibility, and require supervision $\left({ }^{17}\right)$.

\section{The relation between the quality of work life and employee satisfaction}

Employee satisfaction means that employees are pleased with their work and position, they feel management is care about them, and they are comfortable in their work environment - both with other staffers, and with the resources they have available to complete their jobs $\left({ }^{18}\right)$.

Through QWL process, the organizations respond to employee needs by developing mechanisms to allow employee to share in making decisions that design their work lives. This process enables employees to offer distinguished services and products that lead organizations to be more productive, profitable and efficiency $\left({ }^{19}\right)$.

QWL is an employee satisfaction with a variety of needs through resources, activities, and outcomes stemming from participation in the workplace. Employees with an effective QWL tend to report high levels of satisfaction and lower levels of turnover $\left({ }^{20}\right)$. QWL not only affects employees satisfaction but also their family lives, leisure, and other personnel needs. When employees' requirements are not met, they are likely to experience work-life stress which may have adverse consequences on their jobs performance and their own life $\left({ }^{21}\right)$. Once the employees experience enjoyment in work, they would feel satisfied and influence their commitment in their tasks. A happy employee will experience positive feeling and this feeling is carried to their family and the society $\left({ }^{22}\right)$.

\section{Methodology}

The objectives of this paper are to investigate the relationship between quality of work life and employees' satisfaction and also to identify which QWL dimensions have the highest effect on employee's satisfaction. To achieve these objectives; a self-structured questionnaire was designed and distributed to employees at five star hotels in Cairo. This method was thought to be appropriate for collecting data due to the relatively large numbers of employees intended to be surveyed. This questionnaire was designed based on Walton's dimensions of QWL (1975). Five star hotels located in Cairo were selected as the population of the study, because it is one of the most important destinations in Egypt and has a large number of hotels which fit the purpose of the study. The data used for the current study was collected from employees at food and beverage department during the period of July to September2014. The food and beverage department was the choice because it is one of the most important departments in hotels which have large number of staff. Total of 330 questionnaires were distributed to employees in five star hotels (12 hotels) in Cairo ( 25 employees in each investigated hotels), after eliminated disregarded incomplete questionnaires (30) because of missing data, 300 questionnaires were coded for data analysis (91\% response rate). Descriptive statistics, which include frequencies and percentages, used to evaluate the quality of work life attributes from employees' point of view. The collected data were coded to be analyzed using the Statistical Package for Social Science (SPSS) version 20. 


\section{Data Analysis}

\section{A) Descriptive Statistics}

\section{1 - The evaluation the quality of work life attributes from employees' point of view}

Table (1) the nonverbal communication types that have larger affect guest satisfaction

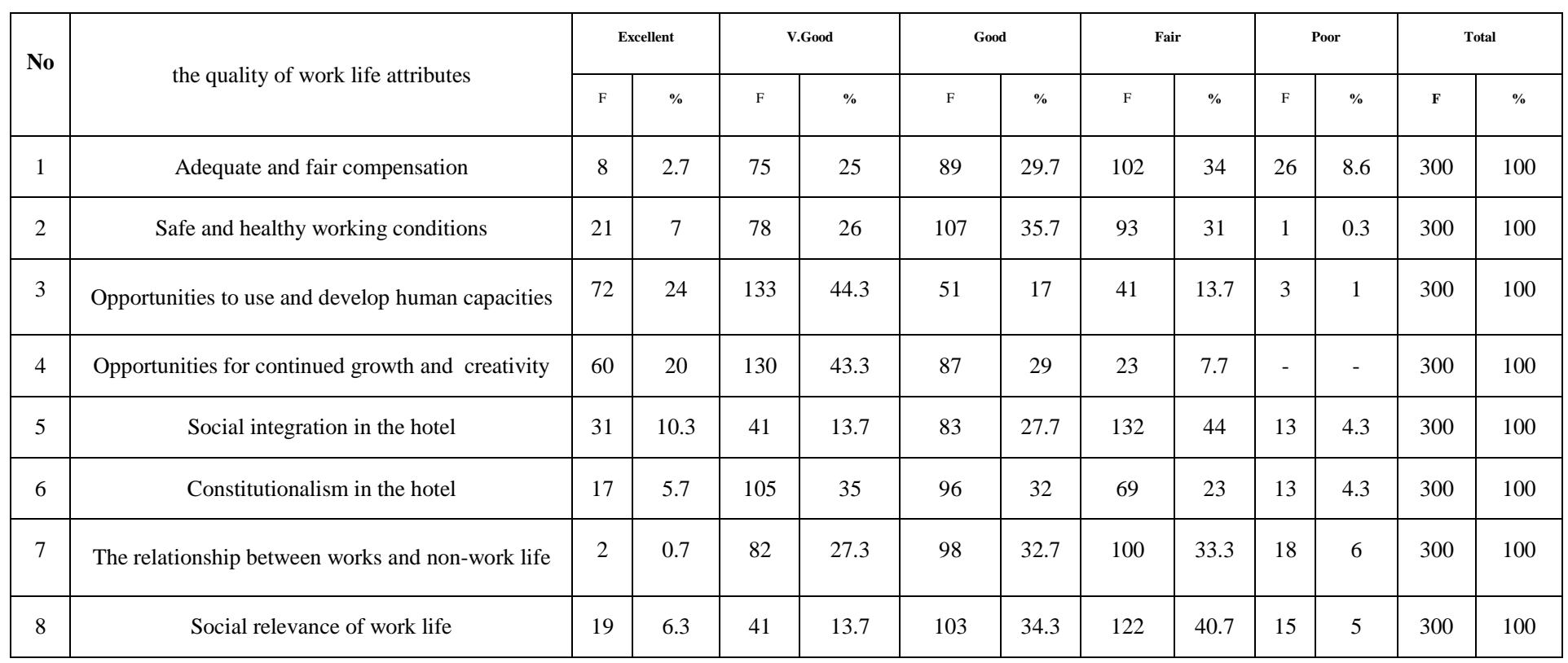

\section{F- Frequencies $\quad \%$ - Percentage}

\section{Table (1) illustrated the following results:-}

* (34\%) of employees indicated that income and compensation system used in hotels was fair, whereas (29\%)of employees indicated that income and compensation system was good and (25\%) of employees stated that income and compensation system was very good.

* $(35 \%)$ of employees indicated that safe and healthy working conditions in hotels were good,(31\%) of employees indicated that safe and healthy conditions were fair, $(26 \%)$ of employees indicated that they were very good.

*The majority of employees (44\%) defined that opportunities to use and develop human capacities were very good, (24\%) of employees indicated that that opportunities to use and develop human capacities were excellent and (17\%) of employees indicated that they were good.

* Most of employees (43\%) indicated that opportunities for continued growth, creativity and development were very good, $(29 \%)$ of employees indicated that they were good.(20\%) of employees indicated that they were excellent.

* Most of employees (44\%) indicated that social integration in the hotel was fair, (27\%)of employees indicated that it was good and (13\%)of employees indicated that it was very good.

* $(35 \%)$ of employees shown that constitutionalism in the hotel was very good, $(32 \%)$ of employees indicated that it was good and $(23 \%)$ of employees indicated that it was fair.

* The majority of employees (33\%) shown that the relationship between works and non-work life were fair, $(32 \%)$ of employees indicated that it was good, $(27 \%)$ of employees indicated that it was very good.

*Finally, (40\%) of employees shown that social relevance of work life was fair, (34\%) of employees indicated that it was good, (13\%) of employees indicated that it was very good.

2-(41\%) of employees mentioned the quality of work life was good, whereas (33\%) of employees shown that it was fair, (21\%) of employees indicated that it was very good, and finally (4\%) of employees stated that it was excellent. 


\section{3- Guests' demographics characteristics analysis:-}

* $(70 \%)$ of employees were male and $(30 \%)$ were female.

$*(53 \%)$ of employees were greater than 25 to35 years old, (26\%) of employees were greater than 36 to 45 years old, (11\%) and of employees were less than 25 years old, and (10\%)were greater than 45 years old.

$*(57 \%)$ of employees were have more than 3 to 6 years of experience, $(15 \%)$ of employees were have more than 6 to 9 years of experience, and (19\%) of employees were have less than 3 years of experience, and finally ( $9 \%$ ) of employees were have more than 9 years of experience.

\section{B) Regression Analysis}

\section{4- The relationship between quality of work life attributes and employees satisfaction}

This section studies the relation between the quality of work life attributes (independent variables) and employee's satisfaction (dependent variable). The Multi Log Regression Model was used to study this relation.

Table (2) Model Summary

\begin{tabular}{|c|c|c|c|c|}
\hline Model & $\mathrm{R}$ & R Square & Adjusted R Square & Std. Error of the Estimate \\
\hline 1 & $.741^{\mathrm{a}}$ & .549 &. $\mathbf{5 3 7}$ & .57762 \\
\hline
\end{tabular}

a. Predictors: (Constant), social, develop, growth, balance, constitutionalism, security, integration, salary

Table (3)

ANOVA $^{\mathrm{a}}$

\begin{tabular}{|c|c|c|c|c|c|}
\hline Model & $\begin{array}{c}\text { Sum of } \\
\text { Squares }\end{array}$ & df & Mean Square & F & Sig. \\
\hline Regression & 118.255 & 8 & 14.782 & 44.304 & $\mathbf{. 0 0 0}^{\mathbf{b}}$ \\
Residual & 97.091 & 291 & .334 & \\
Total & 215.347 & 299 & & & \\
\hline
\end{tabular}

a. Dependent Variable: QWL

b. Predictors: (Constant), social, develop, growth, balance, constitutionalism, security, integration, salary

Table (4) Coefficients ${ }^{\mathrm{a}}$

\begin{tabular}{|c|c|c|c|c|c|}
\hline \multirow{2}{*}{ Model } & \multicolumn{2}{|c|}{ Unstandardized Coefficients } & \multirow{2}{*}{$\begin{array}{c}\begin{array}{c}\text { Standardized } \\
\text { Coefficients }\end{array} \\
\text { Beta }\end{array}$} & \multirow{2}{*}{$\mathrm{t}$} & \multirow{2}{*}{ Sig. } \\
\hline & B & Std. Error & & & \\
\hline (Constant) & .669 & .167 & & 4.005 & .000 \\
\hline adequate income & .321 & .050 & .378 & 6.404 & .000 \\
\hline safe and healthy & .272 & .047 & .297 & 5.722 & .000 \\
\hline Develop & $-.025-$ & .036 & $-.029-$ & $-.702-$ & .483 \\
\hline Growth & $-.038-$ & .041 & $-.038-$ & $-.926-$ & .355 \\
\hline Integration & $-.042-$ & .045 & $-.052-$ & $-.914-$ & .361 \\
\hline constitutionalism & .088 & .043 & .102 & 2.074 & .039 \\
\hline
\end{tabular}




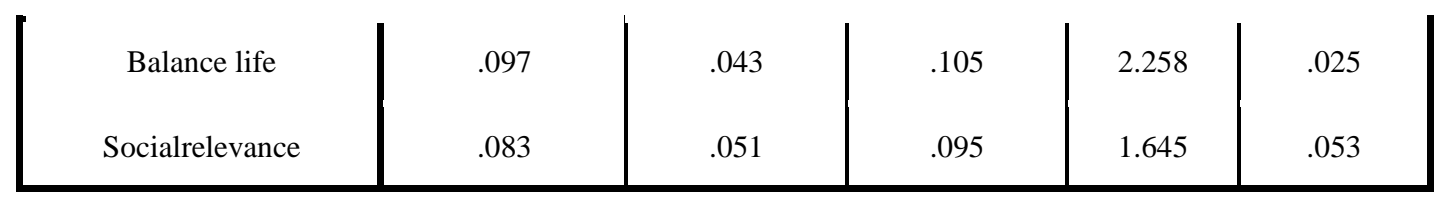

a. Dependent Variable: QWL

From tables (2), (3) and (4) the following results are driven:-

* The QWL has a high significant effect on employees satisfaction of $(\mathrm{P}<0.001)$ table 3.

*The determinant of coefficient "Adjusted $\mathrm{R}^{2}$ equal (0.53). It means that all the independent variables (the quality of work life attributes) together explain 53\% from all the total variance in employees satisfaction (table 2).

*The regression between (adequate income and fair compensation) and employees satisfaction was 0.38 with a high significance $\mathrm{p}$-value $(\mathrm{P}<0.001)$, this high significant $(\mathrm{P}<0.001)$ relationship indicates that adequate income and fair compensation has a positive relationship with employees satisfaction.

*The regression between (safe and healthy working conditions) and employees satisfaction were 0.30 with a high significance $\mathrm{p}$-value $(\mathrm{P}<0.001)$. This high significant relationship indicates that these Safe and healthy working conditions have positive relationship with employees satisfaction.

*The regression between (constitutionalism in the hotel) and employees satisfaction was 0.10 with a significance $\mathrm{p}$-value $(\mathrm{P}<0.05)$, this relation indicates that constitutionalism in the hotel has a positive relationship with employees satisfaction.

*The regression between the variable (the relationship between works and non-work life) and employees satisfaction was 0.11 with a significance $\mathrm{p}$-value $(\mathrm{P}<0.05)$, this relation indicates that the relationship between works and non-work life has a positive relationship with employees satisfaction.

*The regression between (social relevance of work life in the hotel) and employees satisfaction was 0.10 with a significance $\mathrm{p}$-value $(\mathrm{P}<0.05)$, this relation shows that social relevance of work life has a positive relationship with employees satisfaction.

*Furthermore there is a small negative insignificant regression between the variables (opportunities to use and human capacities, opportunities for continued growth and creativity, and social integration in the hotel) and employees satisfaction $(-0.03, \mathrm{P}=0.5)(-0.04, \mathrm{P}=0.4)(-0.05, \mathrm{P}=0.24)$ respectively.

\section{5-The relationship between demographics characteristics of employees, QWL Attributes and employees satisfaction}

\section{A) Gender}

Table (5)The relationship between gender with QWL attributes and employees satisfaction

\begin{tabular}{|c|c|c|}
\hline Constant & Beta & Sig. \\
\hline Male & 0.16 & .000 \\
\hline Female & 0.24 & .02 \\
\hline
\end{tabular}

* Table 5 shows that

the effect of QWL on

employee satisfaction for female $(0.24, \mathrm{P}<0.05)$ was greater than male $(0.15 \mathrm{P}<0.05)$. 


\section{Age}

TTable (6) The relationship between aged with QWL attributes and employees satisfaction

\begin{tabular}{|c|c|c|}
\hline Constant & Beta & Sig. \\
\hline Aged under 25 & 0.33 & .05 \\
\hline Aged greater than 25 to 35 & .17 & .02 \\
\hline Aged greater than 35 to 45 & .24 & .03 \\
\hline Aged over 45 & .38 & .04 \\
\hline
\end{tabular}

* Table 6 demonstrated that the effect of QWL on employee satisfaction foraged over 40 years $(0.38, \mathrm{P}<0.05)$ was greater than aged under 25 years $(0.33, \mathrm{P}<0.05)$ and agedbetween 35 to 45 years $(0.24, \mathrm{P}<0.05)$ and agedbetween 25 to 35 years $(0.17, \mathrm{P}<0.05)$.

\section{C) Years of Experience :}

Table (7) the relationship between years of experiences with QWL Attributes and employees satisfaction

\begin{tabular}{|c|c|c|}
\hline Constant & Beta & Sig. \\
\hline Less than 3 years & .61 & .000 \\
\hline Between $(3-6)$ years & .75 & .000 \\
\hline Between $(6-9)$ years & .44 & .003 \\
\hline More than 9 years & .72 & .000 \\
\hline
\end{tabular}

* Table 7 demonstrated that the effect of the effect of QWL on employee satisfaction for employees with years of experiencesbetween 3 and 6 years $(0.75, \mathrm{P}<0.001)$ was greater than employees with years of experiences more than 9 years and $(0.72, \mathrm{P}<0.001)$ and employees with years of experiences less than 3 years $(0.61, \mathrm{P}<0.001)$ and employees with years of experiences between 6 and 9 years $(0.44, \mathrm{P}<0.05)$.

\section{Discussion}

*The results of this study indicated that the quality of work life attributes have a high significant effect (53\%) on employees satisfaction. This results agreed with (Robbins, 1998) who indicated that QWL is an employee satisfaction with a variety of needs through resources, activities, and outcomes stemming from participation in the workplace. Employees with an effective QWL tend to report high levels of satisfaction, performance and lower levels of turnover $\left({ }^{20}\right)$.

*Among the quality of work life attributes, adequate income and fair compensation, and safe and healthy working conditions have the greatest relation with employees' satisfaction. It agreed with (Walton,1975) who stated that adequate and fair compensation is one of the most important dimensions of the quality of work life and organizations must provide working conditions that are physically and psychologically safe for their employees $\left({ }^{12}\right)$.

*On the other hand, opportunities to use and human capacities, opportunities for continued growth and creativity and social integration in the work organization have small negative effect on employees satisfaction 
* the quality of work life attributes effect on employees satisfaction for female more than male, for guest aged over 40 years more than other ages and for employees with years of experience between 3 and 6 years more than others.

*When employees experience a good quality of work life, hotels can expect various long-term advantages, such as higher employee productivity, lower turnover and absenteeism, increased satisfaction and loyalty towards the hotels and increased overall profitability. This agreed with (Markham, 2010) who identified that a good QWL leads to enhanced organizational efficiency and employee efficiency. He added that organizational efficiency is enhanced through better working condition, improvement in organizational environment, reduction in cost and improved productivity. Whereas, individual Efficiency is enhanced through human resources practices leading to enhanced motivation, job commitment and satisfaction $\left({ }^{15}\right)$.

\section{Recommendations}

- The following recommendations are suggested and directed to hotel's management in order to improve the QWL attributes that will lead to increase employees' satisfaction:-

- Pay more attention to QWL dimensions (such as adequate income and fair compensation, and safe and healthy working conditions). As a result, they will clearly affect the outcome of the hotels and improve and increase employees' satisfaction.

- Use motivators other than compensation and salary (such as, providing adequate conditions for work, perfect appreciation of their work; develop a sense of belonging and collaboration to do duty, sympathetic understanding etc.).

- Establish appropriate work rules and norms that can help to create and maintain an orderly atmosphere that is pleasant to work in where employees can work effectively and also to improve quality of work life.

- Encourage open communication between employees and management.

- Ensure that employees are treated fairly and they follow the same rules.

- Encourage team works to help employees work more effectively and efficiently in order to accomplish organization mission.

- The work environment should be designed in a way that provides the essential conditions for the creation of collaboration and morale of collective work in all levels of the organizational structure.

\section{References}

- Lokanadha. R, and Mohan R, (2010), "Quality of work life of employees: emerging dimensions", Asian Journal of Management Research, ISSN 2229 - 3795, pp: 827- 832.

- Rose, R.., Beh, L., Uli, J. and Idris, K. (2006), "Quality of work life: implications of career dimensions", Journal of Social Sciences, Vol. 2 No. 2, pp. 61-7.

- Sarina, M. and Abdullah, M., (2011), "Quality Work Life among Factory Workers in Malaysia", Asia Pacific International Conference on Environment-Behaviour Studies, Salamis Bay Conti Resort Hotel, Famagusta, North Cyprus, 7-9 December 2011, $739-745$

- Che, R., Beh, L., Uli, J., and Idris, K. (2006), "An Analysis of Quality of Work Life (QWL) and Career- Related Variables. American Journal of Applied Sciences, 3(12), 2151-2159.

- Elivesta, S. (2006),"Relationship among Perception of Quality of Work Life and Job Satisfaction", Management and Organizational review, Vol. 2, No.3, pp.459-460.

- Rajeswara, R. and Bakkappa, B. (2009), "Modeling Approach to the Analysis of the Influence Life in Call Centre Industries using Optimization techniques", JK Journal of Management \& Technology, Volume 1, Number 1 (2009), pp. 78.

- Singh, T., and Kumar, S. (2012), "QWL and Organization Efficiency: A Proposed Framework", Journal of Strategic Human Resource Management, Volume 1, Issue 1, January 2012, pp10-11.

- Greenberg J, and Baron R. (1997)," Behavior in organizations", 6th Editions. New Jersey: Prentice-Hall- Inc. Englewood Cliffs, p.33.

- Che Rose, R.,Beh, L., Uli, J., and Idris, K. (2006), "An Analysis of Quality of Work Life (QWL)

- Pranee, C. (2010), "Correlate with Definition of QWL", The International Journal of Organizational Innovation, Vol. 2, No.3, pp.124-137.

- King, A. and Ehrhard, B. (1997), "Diagnosing organizational commitment: an employee cohesion exercise", International Journal of Management, Vol. 14 No. 3, pp. 317-320.

- Sirgy, J., Reilly, N., Wu, J., and Efraty, D. (2008) "AWork-Life Identity Model of Well-Being: Towards a Research Agenda Linking Quality-of-Work-Life (QWL) Programs with Quality of Life (QOL), The International Society for Quality-of-Life Studies, (ISQOLS), 28 November 2008 
- Walton, R. (1975),"Criteria for quality of working life", the free press, New York: NY, pp. 91-104.

- Lewis, S. (1997), "An International Perspective on Work-Family Issues". In: S. Parasuraman and J.H. Greenhaus eds Integrating Work and Family: Challenges and Choices for a Changing World. Westport, CN: Quorum Books.

- Rethinam, G. (2008),"Constructs of Quality of Work Life: A Perspective of Information and Technology Professionals", European Journal of Social Sciences, 7(1), 58-70.

- Markham, L., (2010), "Quality of work life as predictor of employees", European Journal of Social Sciences - Vol. 7, No. 1, PP: 58-70.

- Huang, T. (2007), "The effects of quality of work life on commitment and turnover intention", Social Behavior and Personality: An international Journal, Vol.35, No.6, pp735-760.

- Schuler, R. S. and Jackson, S. E. (2004), “Human Resource Management: A Critical Text”, London: International Thomson,

- Luthans, F. (2005), “Organizational Behavior”, 9th edition, New York: McGraw Hill Co. pp. 188.

- Sageer, A., Rafat, s., and Agarwa, P.(2012),"Identification of Variables Affecting Employee Satisfaction and Their Impact on the Organization" Journal of Business and Management, Volume 5, Issue 1 (Sep-Oct. 2012), PP 32-39.

- Robbins, S.P., (1998), Organisational Behaviour, eight ed. Simon and Schuster, New Jersey.

- Sirgy, J., Efraty, D., Siegel, P., and Lee, D. (2001),"A new measure of quality of work life (QWL) based on need satisfaction and spillover theories". Social Indicators Research 55 (3), 241-302.

- Gallie, D. (2005), "Work pressure in Europe 1996-2001: trends and determinants", British Journal of Industrial Relations, Vol. 43 No. 3, pp. 351-75

- Bagtasos, M. (2011),"Quality of work life: A review of literature", Business \& Economics Review , 20.2, 1-8.

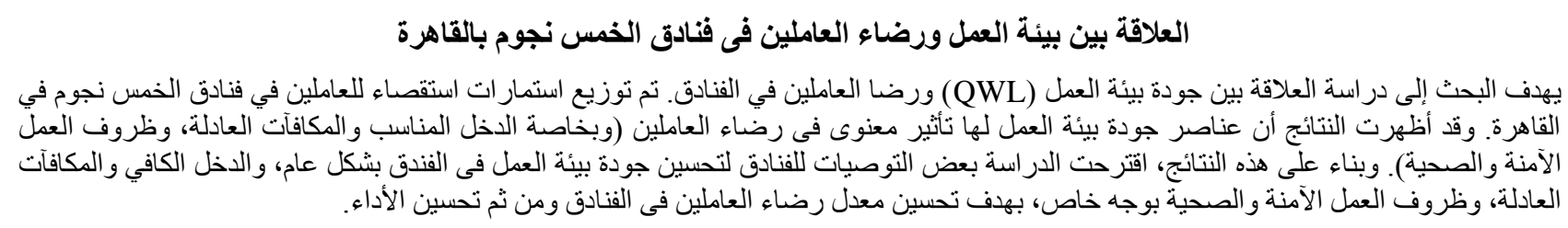

